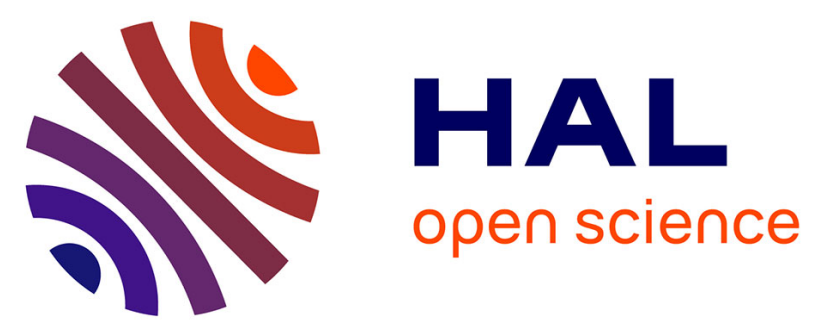

\title{
Formation of phyllosilicates in a fault zone affecting deeply buried arkosic sandstones: their influence on petrophysic properties (Annot sandstones, French external Alps)
}

Henri Leclere, Martine Buatier, Delphine Charpentier, Jean-Pierre Sizun,

Pierre Labaume, Thibault Cavailhes

\section{To cite this version:}

Henri Leclere, Martine Buatier, Delphine Charpentier, Jean-Pierre Sizun, Pierre Labaume, et al.. Formation of phyllosilicates in a fault zone affecting deeply buried arkosic sandstones: their influence on petrophysic properties (Annot sandstones, French external Alps). Swiss Journal of Geosciences, 2012, 105 (2), pp.299-312. 10.1007/s00015-012-0099-z . hal-00795551

\section{HAL Id: hal-00795551 \\ https://hal.science/hal-00795551}

Submitted on 27 Nov 2021

HAL is a multi-disciplinary open access archive for the deposit and dissemination of scientific research documents, whether they are published or not. The documents may come from teaching and research institutions in France or abroad, or from public or private research centers.
L'archive ouverte pluridisciplinaire HAL, est destinée au dépôt et à la diffusion de documents scientifiques de niveau recherche, publiés ou non, émanant des établissements d'enseignement et de recherche français ou étrangers, des laboratoires publics ou privés. 


\title{
Formation of phyllosilicates in a fault zone affecting deeply buried arkosic sandstones: their influence on petrophysic properties (Annot sandstones, French external Alps)
}

\author{
Henri Leclère $\cdot$ Martine Buatier $\cdot$ Delphine Charpentier $\cdot$ Jean-Pierre Sizun • \\ Pierre Labaume $\cdot$ Thibault Cavailhes
}

Received: 30 November 2011/Accepted: 22 May 2012/Published online: 2 August 2012

(C) Swiss Geological Society 2012

\begin{abstract}
The Restefond fault, located in the Late EoceneEarly Oligocene Alpine foreland basin, affects the well lithified and low porosity Grès d'Annot. The fault core zone is characterized by the occurrence of highly deformed sandstone lenses. Deformation inside the lenses corresponds to $\mathrm{mm}$ to sub-mm-spaced cleavage planes rich in phyllosilicates and up to cm-thick and dm-long quartz-calcite pure extensional veins. The cleavages are mostly composed of newlyformed synkinematic white mica and chlorite. By using thermodynamic thermometers based on the chemical composition of chlorite, a temperature of $200 \pm 20{ }^{\circ} \mathrm{C}$ of fault activity was computed. This temperature shows that the Restefond fault was active at burial conditions comprised between 6.5 and $8 \mathrm{~km}$, assuming a mean geothermal gradient between 25 and $30{ }^{\circ} \mathrm{Ckm}^{-1}$. The petrophysic properties of sandstones from the core zone and in the hanging and foot wall of the fault were determined on drilled plugs following three spacial directions. The permeability of the highly deformed sandstone from the core zone is about one order of magnitude higher than in the host rock. This increase in permeability occurs in the direction parallel to the $\mathrm{S}-\mathrm{C}$ structures and is explained by the occurrence of well-
\end{abstract}

Editorial handling: Fernando Nieto Garcia and Edwin Gnos.

Electronic supplementary material The online version of this article (doi:10.1007/s00015-012-0099-z) contains supplementary material, which is available to authorized users.

H. Leclère $(\bowtie) \cdot$ M. Buatier · D. Charpentier · J.-P. Sizun UMR 6249, Université de Franche-Comté, CNRS,

16 Route de Gray, 25030 Besançon Cedex, France

e-mail: henri.leclere@univ-fcomte.fr

P. Labaume $\cdot$ T. Cavailhes

UMR 5243, Université de Monptellier 2, CNRS,

Place Eugène Bataillon, 34095 Montpellier Cedex 5, France connected micropores localized between platy phyllosilicates. This study shows that the fault petrophysic properties are mostly controlled by the precipitation of synkinematic phyllosilicates under deep burial conditions.

Keywords Fault · Phyllosilicates · Petrophysics . Annot sandstones $\cdot$ Temperature $\cdot$ External Alps

\section{Introduction}

Clay minerals are common minerals in fault zones. Their abundance and textural arrangement can play a crucial role on fault frictional and hydrological properties (Rice 1992; Vrolijk and Van der Pluijm 1999; Haines and Van der Pluijm 2008). However, little is known about the deformation structures, the petrophysical properties and the role of phyllosilicates in highly buried fault zones.

In the last four decades, considerable works have been done to understand the petrophysical properties of fault zones affecting high-porosity (10-15\%) siliciclastic sediments in shallow contexts (e.g., Aydin 1978; Antonellini and Aydin 1994; Aydin 2000; Fisher and Knipe 2001; Rawling and Goodwin 2003; Fossen et al. 2007). Deformation in high porosity granular materials is characterized by the development of small millimetric displacement along deformation bands, with an evolution from zones of deformation bands to slip surfaces with increasing offset (Aydin 1978; Fossen et al. 2007). A typical result is that the development of deformation bands in fault zones reduces fault transmissibility, thus providing an effective barrier to fluid flow (Antonellini and Aydin 1994; Antonellini et al. 1999).

By contrast, in low-porosity, well lithified rocks, deformation is generally characterized by open fractures which act as fluid conduits in fault damage zones (Caine 
et al. 1996). Nevertheless, our knowledge on faults formed in low porosity, well lithified sandstones in deep diagenesis contexts remains relatively sparse, even if they are becoming increasingly important targets for hydrocarbon exploration and groundwater aquifers.

In this paper, we describe a normal fault zone formed in deep burial conditions in the Grès d'Annot, a PriabonianRupelian siliciclastic turbidite formation of the Alpine foredeep in SE France. The aim of the study is to determine the origin and conditions of formation of phyllosilicates and their role played on fault zone petrophysic properties. Therefore, in the first part of the paper, we describe deformation microstructures associated with phyllosilicates and we use the chemical composition of the newly-formed chlorite as a basis for estimating their temperatures of formation. In the second part, we quantify petrophysic properties of the host rock and fault zone and compare these data with mineralogical composition and microstructures of the sandstones.

\section{Geological setting}

The Grès d'Annot Formation was deposited from the Early Bartonian (Priabonian in the study area) - to the Middle Rupelian in the south-western Alps foreland basin (Du Fornel et al. 2004) (Fig. 1a). It is mainly composed of deepwater siliciclastic turbidites, with a maximum thickness of 1,000-1,200 m (Riche et al. 1987; Apps et al. 2004; Joseph and Lomas 2004). The sandstone beds range in thickness from a few millimeters to more than $10 \mathrm{~m}$ and are generally interbedded with silty shale beds. The Grès d'Annot deposition ceased with the rifting of the Mediterranean margin (Seranne 1999) and the emplacement of the Schistes-à-Blocs Formation, interpreted as marine deposits at the front of the Embrunais-Ubaye Nappes (Kerckhove 1969; Elliott et al. 1985; Apps et al. 2004; Joseph and Lomas 2004).

Thrusting above the Grès d'Annot occurred during the late Oligocene-Earliest Miocene with the emplacement of the Pennic front (Kerckhove 1969). The thickness of the nappes is estimated to at least $4-5 \mathrm{~km}$ from zircon fission tracks analysis in the Grès du Champsaur Formation at the southern border of the Pelvoux massif (Seward et al. 1999). During the Miocene, basement thrusting dated at $22 \mathrm{Ma}$ (Corsini et al. 2004) uplifted the Argentera and Barrot massifs (Bigot-Cormier et al. 2006), and gravitational equilibration of the thickened crust resulted in the formation of normal faults that cut the nappes and their substratum down to the Palaeozoic basement (Labaume et al. 1989; Du Bernard 2002). The present study is focused on one of these normal faults named Restefond fault, located in the internal part of the foreland basin (Fig. 1b).

The Restefond fault striking E-W and dipping $70^{\circ} \mathrm{N}$ affects the Grès d'Annot and the Schistes-à-Blocs Formation and was active after the emplacement of the allochtonous nappes. The study outcrop is located on a part where the Restefond fault affects the Grès d'Annot formation. The footwall is composed of a succession of decimeter-thick sandstone and mudstone layers, while the hanging-wall is made up of meter-thick sandstone layers (Fig. 2). The bedding in the hanging wall and footwall of the fault is sub-horizontal.

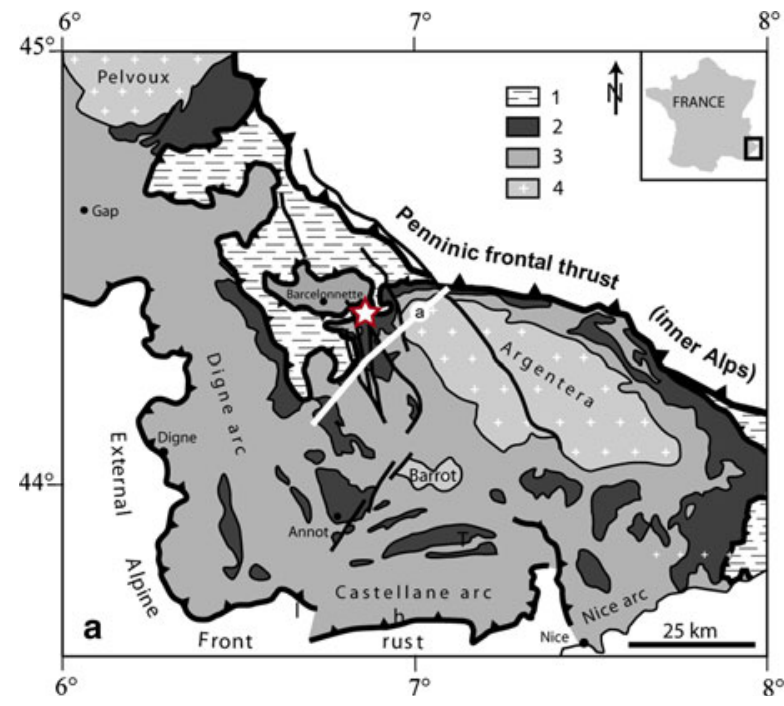

Fig. 1 a Structural map of the SW external Alps, with location of the study area (star). 1 Embrunais-Ubaye nappes, 2 Middle Eocene to Rupelian, i.e. the Grès d'Annot Formation (south of Pelvoux massif: Grès du Champsaur) and its shallow-water lateral equivalents in the Castellane Arc and Barrême basin, and underlying Tertiary strata, 3 $8^{\circ}$

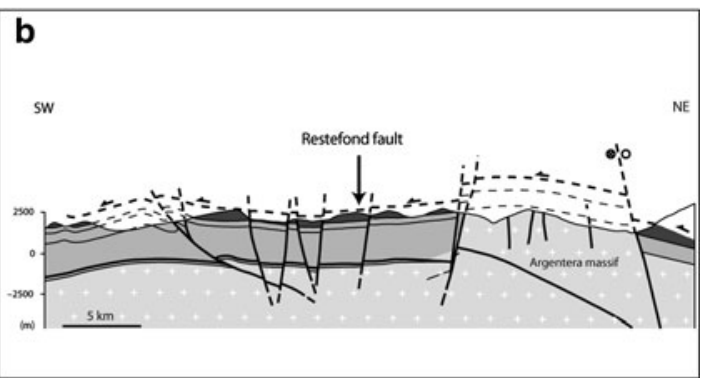

Mesozoic, 4 Palaeozoic substratum (mainly crystalline basement in the Argentera and Pelvoux massifs and Permian sediments in the Barrot massif). b Cross section of the studied area with the location of the Restefond fault. Map and section are simplified from Labaume et al. (2008b). The star on the map localizes the Restefond fault 


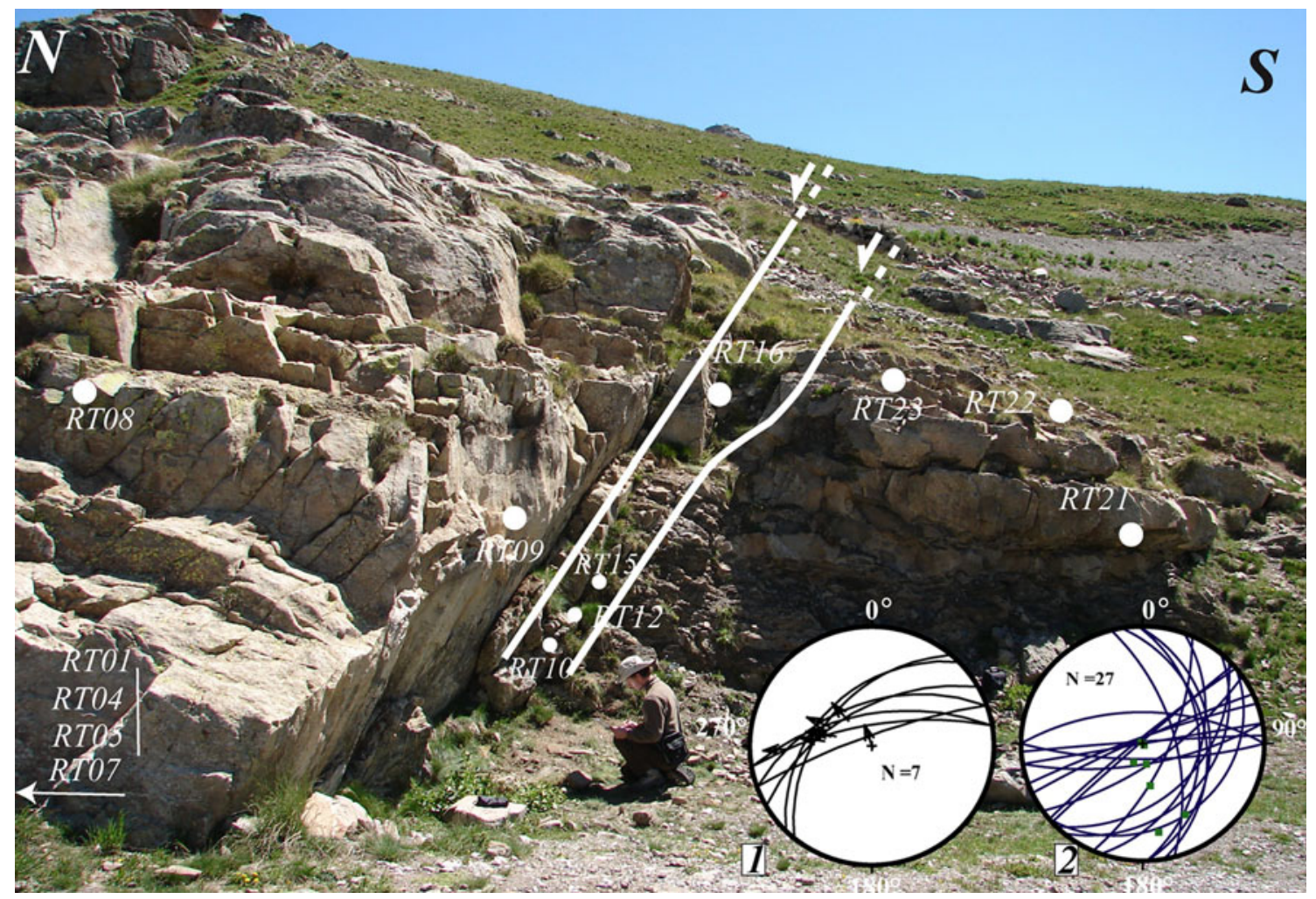

Fig. 2 Field photograph and structural data of the Restefond fault outcrop. Only eight samples are localized on the picture, the other four samples are located in the hanging wall between 12 to $17 \mathrm{~m}$ from the core zone and their position is not visible on this photograph. The footwall is composed of sandstone-mudstone succession while the hanging wall is composed of massive sandstone layers. The core zone is bounded by two major slip surfaces (white lines on photograph) and

The main motion of the Restefond fault is normal with an offset of about 15 meters, even if, the striations are scattered from pure normal dip slip to pure senestral strike slip (Fig. 2, Schmidt diagram 1). The Restefond fault zone comprises two main slickensides which delimitate a 1-m wide zone accommodating the maximal deformation. This zone of maximal deformation is considered as the fault core zone. The core zone is characterized by tilted lenses of deformed sandstone separated by thin mudstone layers (Fig. 2). The deformed lenses concentrate calcite-quartz veins, cleavage surfaces rich-in phyllosilicates, shear planes and fractures (Fig. 3).

\section{Methods}

The petrophysical and mineralogical analyses were carried out along a profile transverse to the fault zone. Representative samples of the deformation-related features were collected in the fault core zone (i.e. in the lenses of deformed sandstone) and in the host sandstone (up to $15 \mathrm{~m}$ away from the core zone) along the selected is composed by imbricated lenses of deformed sandstone (cf. Figs. 3, 4). 1 Schmidt diagram with the plot of shear planes (lines) and striations (arrows indicate the sense of displacement of the upper block); 2 Schmidt diagram with the plot of quartz-calcite extension veins surfaces (lines) and poles of the cleavage planes (green points). Scale is represented by the man in front of the fault

profile. Samples were collected in the same sandstone layer in the fault footwall and core zone. This layer could not be identified in the hanging wall, where a sandstone layer of equivalent grain size was sampled. Samples presenting a penetrative meteoric alteration were excluded.

\subsection{Observations on thin sections}

Thin sections of 12 colored epoxy resin-impregnated samples were examined using optical and scanning electron microscopes (SEM) for petrographical and microstructural study. The orientation of the thin sections was selected in the $\mathrm{X}-\mathrm{Z}$ plane of deformation in order to characterize the microstructures and explain the modifications of the petrophysical parameters.

Semi-quantitative estimations of the mineralogical content and macroporosity were performed by point counting on eight thin sections with an optical microscope equipped with a point counting system. At least 500 points were measured on each thin section. Detrital quartz and phyllosilicates, quartz and calcite cements, fresh and 


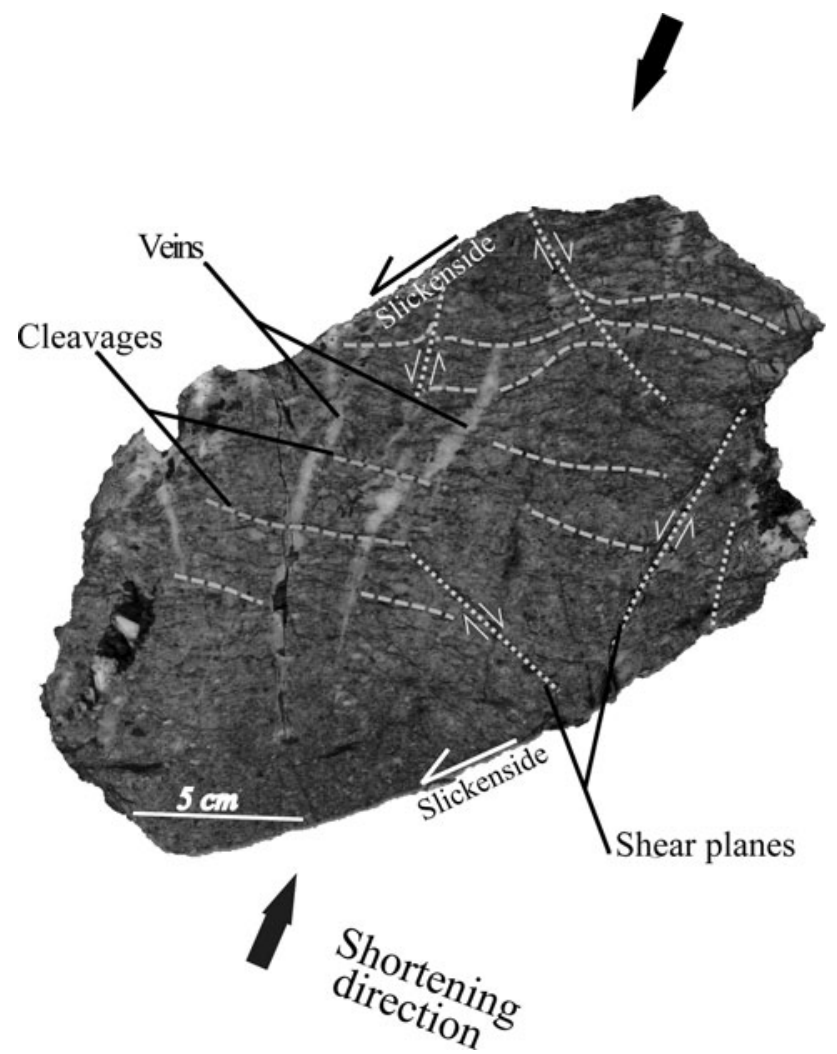

Fig. 3 Polished surface of a hand-sample of a deformed sandstone lens from the fault core zone. The deformation is marked by cleavage planes, quartz-calcite extension veins and shear planes. Cleavage planes correspond to pressure solution surfaces (stylolites) and define a foliation which density increases toward the shear planes bordering the sandstone lens. Newly-formed phyllosilicates (white mica and chlorite) are concentrated along the cleavage and shear planes

altered feldspars, lithic fragments, newly-formed phyllosilicates as well as macropores revealed by colored resin were identified and quantified. Selected thin sections were carbon coated and studied using a Jeol JSM5600 scanning electron microscope coupled with a FONDIS energy dispersive analyzer (EDS). The nature of phyllosilicates, their morphology and their behavior in highly deformed rocks were particularly investigated.

\subsection{Petrophysic analysis}

Petrophysic analyses were done on cylindrical plugs drilled in 12 samples following the three spatial directions (horizontal and parallel to the fault strike, horizontal and perpendicular to the fault strike, and vertical). The diameter of the plugs is $20 \mathrm{~mm}$ and their length is comprised between 25 to $60 \mathrm{~mm}$. The drilling location of the plugs in the rock was chosen to make plugs devoid of veins and fractures, in order to characterize petrophysical modifications linked to matricial properties and not to fractures properties.

\subsubsection{Porosity}

Water porosity measurements were performed using Archimedes' method to quantify total porosity of the drilled plugs. The samples were dried at $60{ }^{\circ} \mathrm{C}$ until they reached a stable mass $\left(\mathrm{m}_{\mathrm{d}}\right)$, then degassed during $12 \mathrm{~h}$ before being progressively saturated with degassed and distillated water. The total porosity $(\mathrm{Nt})$ is given by the expression $\mathrm{Nt}=\left[\left(\mathrm{m}_{2}-\mathrm{m}_{\mathrm{d}}\right) /\left(\mathrm{m}_{2}-\mathrm{m}_{1}\right)\right] \times 100$, where $\mathrm{m}_{1}$ is the mass of the sample weighed under water (hydrostatic weighing) and $\mathrm{m}_{2}$ is the mass of the sample totally saturated by water. The analytical accuracy is $\pm 0.05 \%$.

\subsubsection{Permeability}

Gas permeability data were performed with a Hassler cell permeameter using nitrogen, at steady state conditions: differential fluid pressure of $20 \mathrm{kPa}$ and under a confining pressure of $800 \mathrm{kPa}$. The analytical accuracy varies between $\pm 10 \% \quad(\mathrm{~K} \approx 1 \mathrm{mD})$ and $\pm 0.5 \% \quad(\mathrm{~K} \approx 0.001 \mathrm{mD})$. Although a confining pressure of $800 \mathrm{kPa}$ does not reflect in situ stress conditions, these permeability measures allow us to point out a potential preferential fluid-flow direction.

\subsection{X-ray diffraction (XRD)}

The phyllosilicate mineralogy of 4 representative samples from host rock (RT23, RT3) and from fault core zone (RT10, RT12) was analyzed with a SCINTAG XRD 2000 diffractometer at the Geological Institute of Neuchatel, Switzerland, following the procedures outlined by Kübler (1964) and Adatte et al. (1996). The XRD diffractometer was equipped with a $\mathrm{Cu}$ tube and operated at $45 \mathrm{kV}$ and $40 \mathrm{~mA}$. The phyllosilicate mineralogy was analyzed by $\mathrm{X}$-ray diffraction obtained between $5^{\circ}$ and $60^{\circ}(2 \theta)$ with a step size of $0.03^{\circ}$ and a goniometer speed ranging of $2 \%$ min.

Phyllosilicates-sized fractions $(<2$ and $2-16 \mu \mathrm{m})$ from the selected samples were extracted after carbonate removal. XRD analyses of oriented phyllosilicate samples were made after air drying at room temperature and ethylene-glycol solvated conditions.

\subsection{Microprobe analysis}

The chemical composition ( $\mathrm{Si}, \mathrm{Fe}, \mathrm{Mg}, \mathrm{Al}, \mathrm{Ti}, \mathrm{K}, \mathrm{Ca}, \mathrm{Na}$ ) of white mica and chlorite from the highly deformed core zone of the fault were analyzed at the University of Montpellier 2, using a CAMECA model SX100 electron microprobe equipped with five $\mathrm{X}$-ray spectrometers on 3 carbon coated thin sections from the fault core zone. The microprobe was operated using $20 \mathrm{kV}$ of excitation 
Table 1 Results in percentage of point counting analyses on thin sections from 8 samples

\begin{tabular}{|c|c|c|c|c|c|c|c|c|}
\hline & \multicolumn{4}{|c|}{ Host rock from hanging wall } & \multicolumn{2}{|c|}{ Core zone } & \multicolumn{2}{|c|}{ Host rock from footwall } \\
\hline & RT01 & RT05 & RT07 & RT08 & RT15 & RT10 & RT22 & RT21 \\
\hline Polygenics fragments & 11 & 16 & 14 & 10 & 7 & 6 & 13 & 9 \\
\hline Detrital quartz & 33 & 28 & 40 & 37 & 32 & 22 & 34 & 25 \\
\hline Fresh feldspars & 22 & 23 & 22 & 11 & 14 & 5 & 20 & 19 \\
\hline Altered feldspars & 19 & 13 & 11 & 25 & 20 & 15 & 11 & 20 \\
\hline Detrital phyllosilicates & 3 & 4 & 4 & 3 & 2 & 2 & 3 & 3 \\
\hline New formed phyllosilicates & 6 & 10 & 5 & 5 & 24 & 28 & 8 & 12 \\
\hline Quartz veins & 0 & 0 & 0 & 0 & 0 & 20 & 0 & 0 \\
\hline Calcite cement & 6 & 7 & 4 & 4 & 0 & 0 & 4 & 12 \\
\hline Macroporosity & 1 & 0 & 1 & 4 & 1 & 1 & 5 & 0 \\
\hline Total & 100 & 100 & 100 & 100 & 100 & 100 & 100 & 100 \\
\hline
\end{tabular}

RT01, RT05, RT07, RT08 are located in the hanging-wall; RT10, RT15 are located in the fault core zone and RT22, RT21 are located in the footwall

potential, $10 \mathrm{nA}$ of current intensity and a beam diameter of $3 \mu \mathrm{m}$. The standards used were wollastonite $(\mathrm{Si}, \mathrm{Ca})$, $\mathrm{Fe}_{2} \mathrm{O}_{3}(\mathrm{Fe})$, forsterite $(\mathrm{Mg}), \mathrm{Al}_{2} \mathrm{O}_{3}(\mathrm{Al}), \mathrm{TiO}_{2}(\mathrm{Ti})$, orthoclase $(\mathrm{K})$ and albite $(\mathrm{Na})$.

Temperatures were then estimated using the composition of chlorite and following the methods of Vidal et al. $(2005,2006)$ and then Inoue et al. (2009). Vidal et al. $(2001,2005)$ proposed a thermodynamic model for $\mathrm{Fe}-\mathrm{Mg}$ partitioning of aluminious trioctahedral chlorite $(\mathrm{Si}<3$ p.f.u.). They chose four end-members that allow the $\mathrm{Fe}-\mathrm{Mg}$, Tschermak and dioctahedral-trioctahedral substitutions occurring in trioctahedral chlorite (clinochlore $\left(\mathrm{Mg}_{5} \mathrm{Al}\right.$ ) $\left[\mathrm{Si}_{3} \mathrm{AlO}_{10}\right](\mathrm{OH})_{8}$, daphnite $\left(\mathrm{Fe}_{5}{ }^{2+} \mathrm{Al}\right)\left[\mathrm{Si}_{3} \mathrm{AlO}_{10}\right](\mathrm{OH})_{8}$, amesite $\left(\mathrm{Mg}_{4} \mathrm{Al}_{2}\right)\left[\mathrm{Si}_{2} \mathrm{Al}_{2} \mathrm{O} 10\right](\mathrm{OH})_{8}$ and $\left(\mathrm{Fe}_{4}{ }^{2+} \mathrm{Al}_{2}\right)\left[\mathrm{Si}_{2} \mathrm{Al}_{2} \mathrm{O}_{10}\right]$ $(\mathrm{OH})_{8}$, and sudoite $\left.\left(\mathrm{Mg}_{2} \mathrm{Al}_{3}\right)\left[\mathrm{Si}_{3} \mathrm{AlO}_{10}\right](\mathrm{OH})_{8}\right)$. The simultaneous estimation of $\mathrm{Fe}^{3+}$ in chlorite and equilibrium temperature for the Chl-Qtz- $\mathrm{H}_{2} \mathrm{O}$ assemblage is done at a pressure of $1.5 \mathrm{kbar}$ and a water activity $\mathrm{aH}_{2} \mathrm{O}$ of 1 by using a criterion based on the convergence of equilibria (Vidal et al. 2006). Inoue et al. (2009) used the end-member component of chlorite solid solution Al-free chlorite instead of clinochlore. Using the calibrated thermodynamic properties of Inoue et al. (2009), the formation temperatures of chlorite is estimated using the $\mathrm{XFe}^{3+}$ determined by Vidal et al. $(2005,2006)$.

\section{Results and interpretation}

\subsection{Petrology and deformation microstructures}

\subsubsection{Host rocks}

The sandstone is a lithic arkose following McBride's classification (McBride 1963) and is composed by both detrital and authigenic components. The major components are quartz, K-feldspar and plagioclase grains, metamorphic and magmatic rock fragments and phyllosilicates (muscovite, chlorite and rare biotite). Point counting analyses (Table 1, samples RT01, 05, 07, 08, 21, 22) confirm that feldspar, quartz and polygenic fragments are the major components. Phyllosilicates represent a total of 8 to $15 \%$ of the sandstones, with a significant part of them of authigenic origin (illitization of K-feldspars). Optical microscopy shows that the host sandstones have a very compact texture and that their deformation is weak and mainly represented by sparse intragranular to transgranular fractures and pressure-solution at grain contacts (Fig. 4a). These textures are similar to those observed in the Grès d'Annot sampled away from fault zones in the same area (Labaume et al. 2008b). The host sandstones sampled in the fault footwall and hanging wall can thus be considered as equivalent to the protolith of the deformed sandstone sampled in the fault core zone.

\subsubsection{Fault core zone}

At the macroscopic scale, deformation inside the lenses corresponds to $\mathrm{mm}$ to sub-mm-spaced cleavage planes rich in phyllosilicates and up to $\mathrm{cm}$-thick and decimeter-long quartz-calcite pure extensional veins (Fig. 3). The veins are scattered from parallel to perpendicular to the fault strike (Fig. 2, Schmidt diagram 2). The cleavage planes trend sub-parallel to the fault, with dips scattered between subhorizontal and parallel to the lens borders (Fig. 2, Schmidt diagram 2). The interaction between the cleavages and shear planes defines a S-C structure (Fig. 3). The kinematics of the pure extensional veins and the $\mathrm{S}-\mathrm{C}$ structure are in agreement with the main normal dip slip motion of 

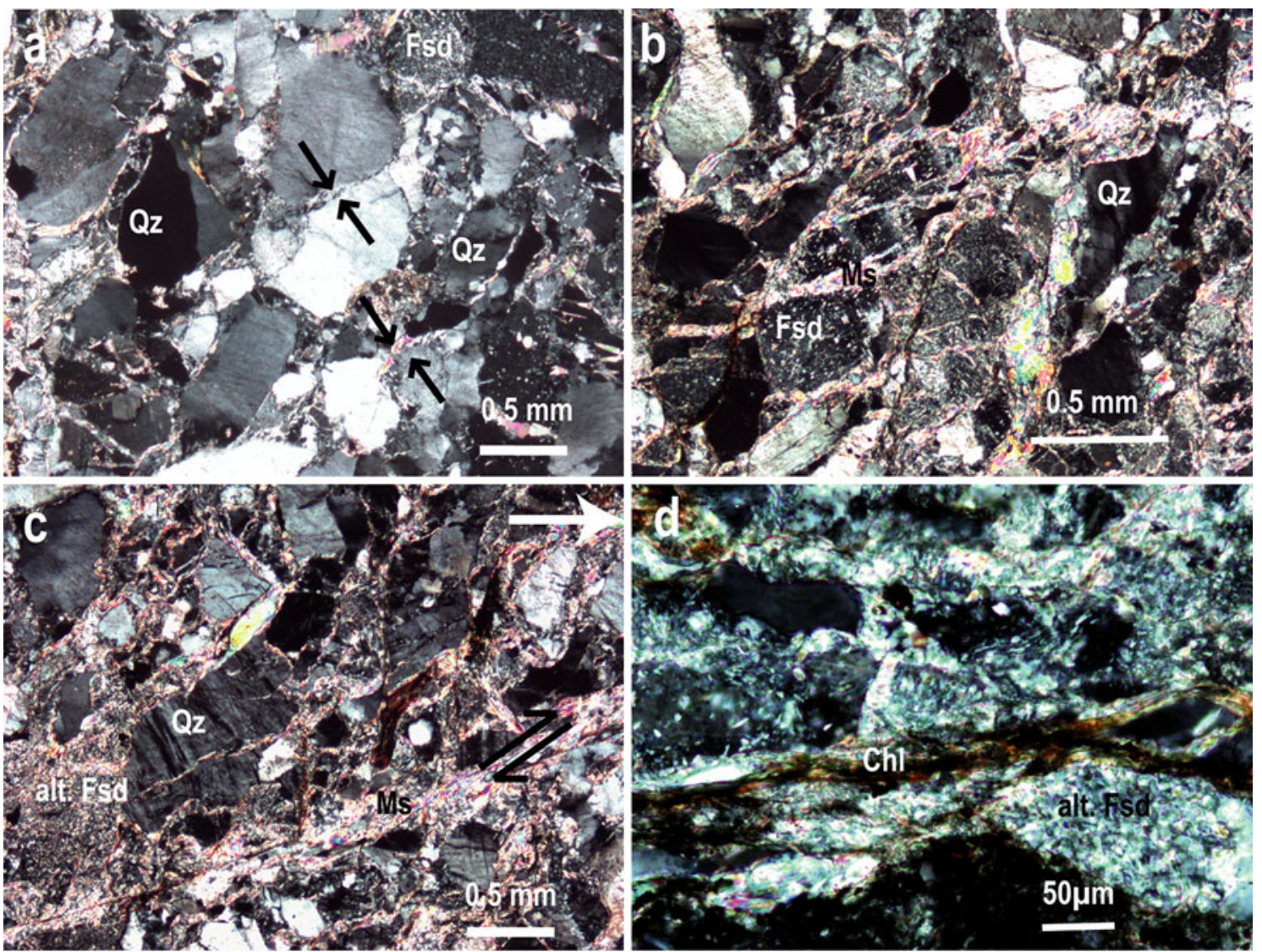

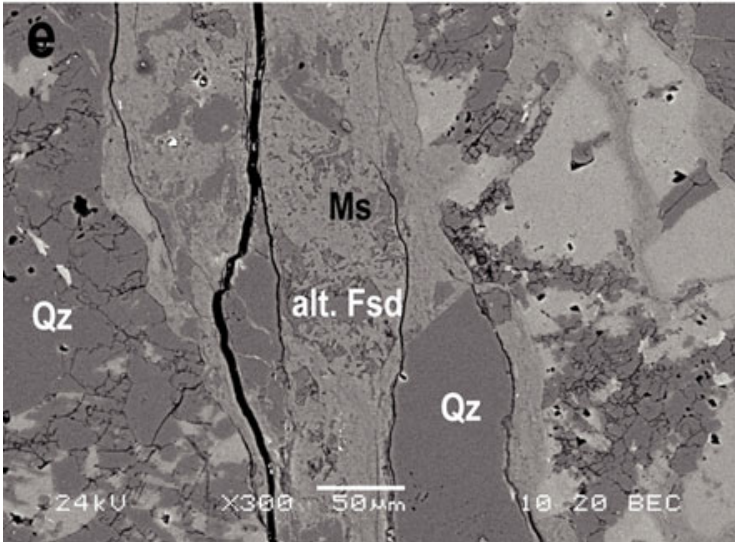

Fig. 4 Optical microscope (a-d) and backscattered scanning electron microscope (e, f) images of the host sandstone (a) and deformed sandstones from the fault zone core (b-f). a Imbricated quartz grains sutured by pressure solution at grain contacts (arrows); $\mathbf{b}$ and $\mathbf{c}$ highly deformed sandstone with newly-formed white mica preferentially oriented along shear surface and as felpspar replacement. The white arrow indicates the vertical direction; d Shear surface with newly

the Restefond fault. Intensity of deformation is variable and generally increases toward the lens borders.

At the microscopic scale, the formation of $\mathrm{S}-\mathrm{C}$ structures corresponds to:

- a passive concentration of phyllosilicates along cleavage planes by a combination of normal shortening

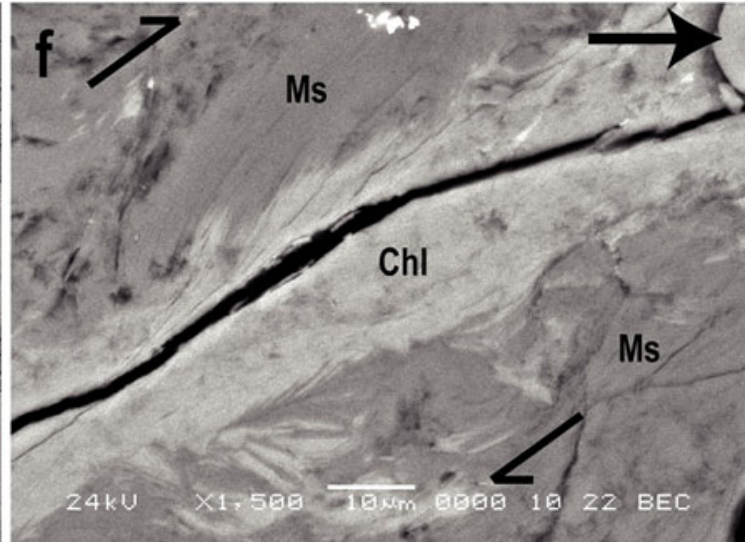

formed mica and chlorite; e SEM image of K-feldspar illitisation along a shear zone; f newly-formed white mica and chlorite preferentially oriented along a shear surface. The evidence of newly-formed phyllosilicates is shown by the interdigitate texture of chlorite and white mica. The black arrow indicates the vertical direction; $Q z$ quartz, Fsd feldspar, $M s$ white mica, Chl chlorite; alt. Fsd altered feldspar

represented by pressure solution of quartz and feldspar alteration (Fig. 4b).

- a concentration of newly-formed phyllosilicates preferentially oriented along shear planes (Fig. 4c, d). Shear planes correspond to transgranular shear fractures with normal dip slip motion (Fig. 3). 

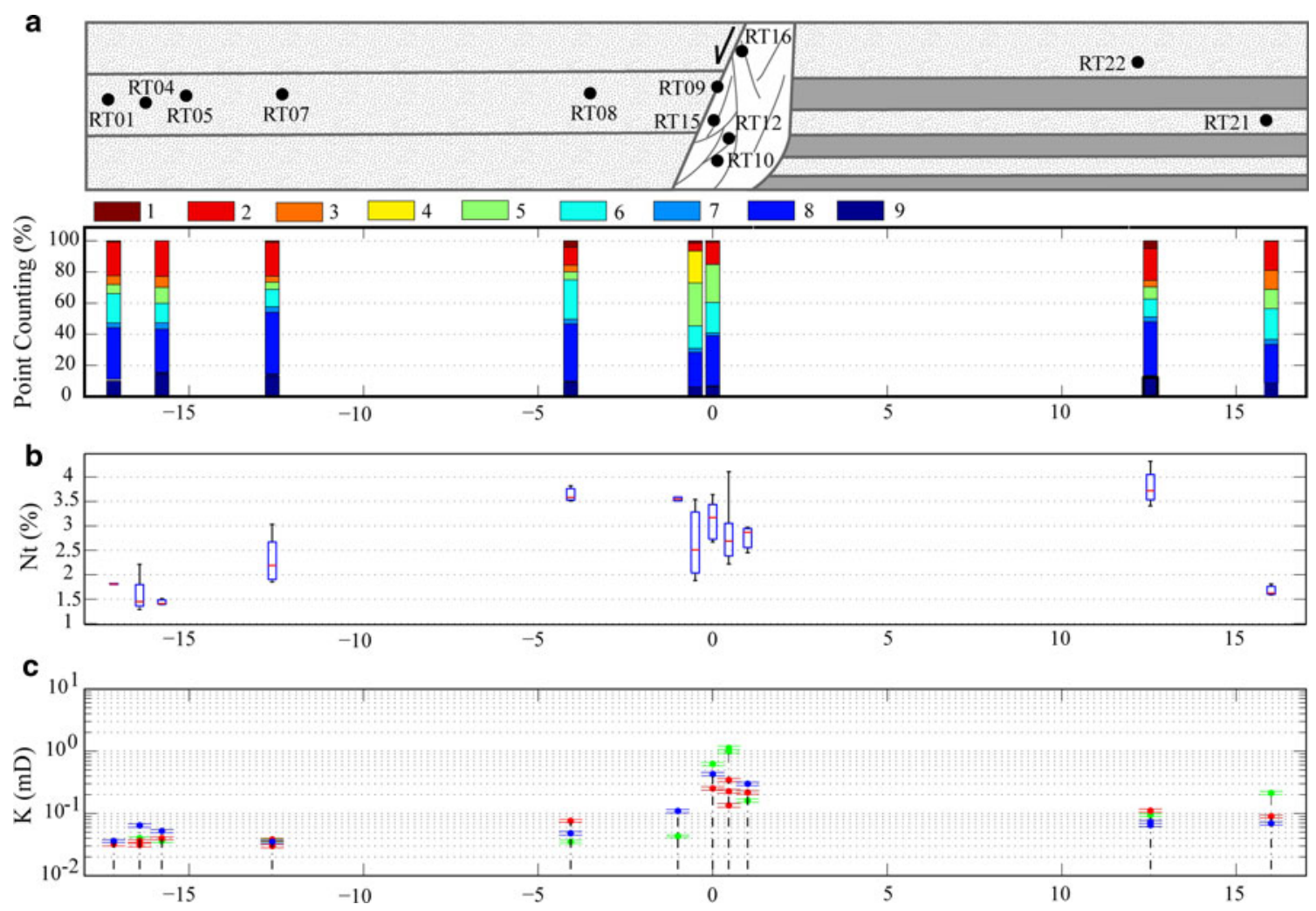

Fig. 5 Petrophysic data and mineralogical composition along the studied profile across the Restefond fault zone. a Mineralogical content obtained by point counting analyses (cf Table 1). 1 Macropores, 2 fresh feldspars, 3 calcite cement, 4 quartz veins, 5 newlyformed phyllosilicates and matrix enriched in phyllosilicates, 6 altered feldspars, 7 detrital phyllosilicates, 8 detrital quartz, 9 polygenic fragments. b Total porosity (Nt). c Permeability values $(\mathrm{K})$ in $\mathrm{mD}$. Core orientation green: horizontal and parallel to the fault; blue: horizontal and perpendicular to the fault; red: vertical
The newly-formed phyllosilicates, comprising white mica and chlorite (Fig. 4e, f), are described in more detail in a following section.

\subsection{Petrophysic measurements}

\subsubsection{Total porosity}

The total porosity values $(\mathrm{Nt})$ of host sandstone samples (RT01, 04, 05, 07, 21) range from 1 to $2 \%$, except for RT08 and RT22 that display higher values around $4 \%$ (Fig. 5a, b; Table 2). These higher values correspond to an increase of porosity due to macropore genesis related to calcite-cement dissolution (Fig. 6). This dissolution can be related to present day meteoric alteration by infiltration. The increase of the macroporosity is thus considered as an artifact not related to faulting processes. If we exclude this artifact, we can consider that the total porosity ( $\mathrm{Nt}$ ) of the host sandstone is close to $2 \%$. These data are in agreement with those measured by Labaume et al. (2008a) in similar highly diagenetized sandstones sampled away from fault zones in the same area.
The porosity values (Nt) measured in samples from the fault zone are about $3 \%$, slightly higher than the porosity values measured in the host sandstone (Fig. 5a, b). This increase can be related to the occurrence of microporosity inside phyllosilicate clusters. Indeed, phyllosilicate content in the deformed sandstones reaches around three times their amount in the host sandstone according point counting analyses (Table 1). On the contrary, macroporosity measured by point counting in thin sections does not show any difference between the host and highly deformed sandstones.

\subsubsection{Permeability}

All the permeability values of the host sandstones are comprised between 0.05 and $0.1 \mathrm{mD}$. Permeability from the fault core zone sandstones is about one order of magnitude higher than in the host sandstone (Fig. 5c). The highest value of permeability reaches $1.2 \mathrm{mD}$.

Considering the permeability measurements done following the three-space directions (cf. Sect. 3), we can notice the following results: 
Table 2 Results of petrophysical measurements

\begin{tabular}{|c|c|c|c|c|c|}
\hline Samples & Orientation & Positions (m) & $\mathrm{K}(\mathrm{mD})$ & Delta K (mD) & $\mathrm{Nt}(\%)$ \\
\hline RT01 & N170 & -17.16 & 0.036 & 0.002 & 1.80 \\
\hline RT01 & $\mathrm{V}$ & -17.16 & 0.032 & 0.002 & 1.82 \\
\hline RT04 & N170 & -16.42 & ND & ND & 1.66 \\
\hline RT04 & N170 & -16.42 & 0.064 & 0.004 & 2.21 \\
\hline RT04 & N80 & -16.42 & 0.04 & 0.002 & 1.45 \\
\hline RT04 & V & -16.42 & 0.036 & 0.002 & 1.38 \\
\hline RT04 & $\mathrm{V}$ & -16.42 & 0.031 & 0.002 & 1.29 \\
\hline RT05 & N170 & -15.78 & 0.052 & 0.003 & 1.51 \\
\hline RT05 & N80 & -15.78 & 0.036 & 0.002 & 1.41 \\
\hline RT05 & $\mathrm{V}$ & -15.78 & 0.04 & 0.002 & 1.39 \\
\hline RT07 & N80 & -12.62 & 0.037 & 0.002 & 1.85 \\
\hline RT07 & N170 & -12.62 & 0.035 & 0.002 & 3.03 \\
\hline RT07 & N170 & -12.62 & ND & ND & 2.19 \\
\hline RT07 & $\mathrm{V}$ & -12.62 & 0.03 & 0.002 & 1.92 \\
\hline RT07 & $\mathrm{V}$ & -12.62 & 0.038 & 0.002 & 2.55 \\
\hline RT08 & N170 & -4.07 & 0.048 & 0.003 & 3.51 \\
\hline RT08 & V & -4.07 & 0.076 & 0.004 & 3.58 \\
\hline RT08 & N80 & -4.07 & 0.035 & 0.002 & 3.82 \\
\hline RT09 & N170 & -1.0 & 0.109 & 0.007 & 3.59 \\
\hline RT09 & N80 & -1.0 & 0.043 & 0.002 & 3.51 \\
\hline RT10 & $\mathrm{V}$ & -0.5 & ND & ND & 1.88 \\
\hline RT10 & $\mathrm{V}$ & -0.5 & ND & ND & 2.51 \\
\hline RT10 & $\mathrm{V}$ & -0.5 & ND & ND & 3.54 \\
\hline RT15 & N170 & 0.0 & 0.43 & 0.028 & 3.37 \\
\hline RT15 & N80 & 0.0 & 0.621 & 0.039 & 3.64 \\
\hline RT15 & $\mathrm{V}$ & 0.0 & 0.252 & 0.016 & 2.75 \\
\hline RT15 & $\mathrm{V}$ & 0.0 & ND & ND & 2.67 \\
\hline RT15 & $\mathrm{V}$ & 0.0 & ND & ND & 3.17 \\
\hline RT12 & N170 & 0.46 & ND & ND & 2.77 \\
\hline RT12 & N80 & 0.46 & 1.132 & 0.073 & 2.39 \\
\hline RT12 & N80 & 0.46 & 0.99 & 0.063 & 4.11 \\
\hline RT12 & N80 & 0.46 & ND & ND & 3.02 \\
\hline RT12 & N80 & 0.46 & ND & ND & 3.15 \\
\hline RT12 & N80 & 0.46 & ND & ND & 2.37 \\
\hline RT12 & $\mathrm{V}$ & 0.46 & 0.344 & 0.022 & 2.22 \\
\hline RT12 & $\mathrm{V}$ & 0.46 & 0.227 & 0.015 & 2.52 \\
\hline RT12 & $\mathrm{V}$ & 0.46 & 0.135 & 0.009 & 2.69 \\
\hline RT16 & N170 & 1.0 & 0.299 & 0.019 & 2.97 \\
\hline RT16 & N80 & 1.0 & 0.161 & 0.01 & 2.45 \\
\hline RT16 & $\mathrm{V}$ & 1.0 & 0.217 & 0.013 & 2.87 \\
\hline RT22 & N170 & 12.54 & 0.065 & 0.004 & 3.41 \\
\hline RT22 & N170 & 12.54 & 0.073 & 0.004 & 3.78 \\
\hline RT22 & N80 & 12.54 & 0.094 & 0.005 & 4.32 \\
\hline RT22 & $\mathrm{V}$ & 12.54 & 0.111 & 0.007 & 3.66 \\
\hline RT21 & N170 & 16.0 & 0.069 & 0.004 & 1.59 \\
\hline RT21 & N80 & 16.0 & 0.213 & 0.013 & 1.81 \\
\hline RT21 & $\mathrm{V}$ & 16.0 & 0.09 & 0.005 & 1.62 \\
\hline
\end{tabular}

The orientation N170 refers to horizontal cores drilled parallel to the fault, N80 refers to horizontal cores drilled perpendicular to the fault and $\mathrm{V}$ refers to vertical cores. The positions of the sample are given following a reference point located in the fault core-zone and with positive values for samples located in the footwall. $\mathrm{K}(\mathrm{mD})$ corresponds to the permeability values and $\mathrm{Nt}$ corresponds to the total porosity values

ND non-determined

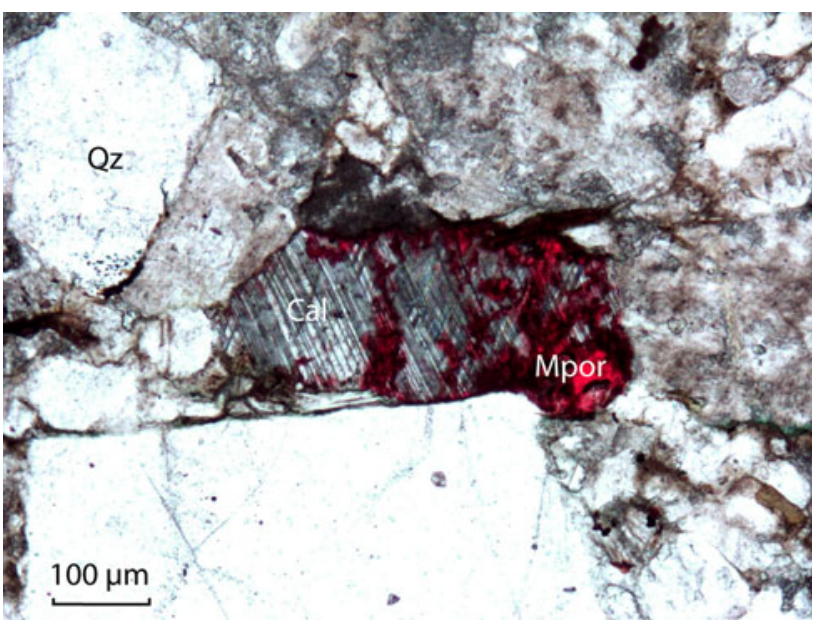

Fig. 6 Optical micrograph of a host sandstone sample with high porosity. Macroporosity (in red) is related to secondary alteration of calcite cement. $Q z$ quartz, $C a l$ calcite, Mpor macroporosity

- The permeability of the samples located in the footwall and the hanging wall doesn't show a preferential direction of fluid flow. This means that the fluid flow outside the fault zone is isotropic.

- The permeability in the three directions of the samples located in the core zone lenses displays a preferential fluid-flow direction. This direction is horizontal and parallel to the fault plane $\left(\mathrm{N} 80^{\circ} \mathrm{E}\right)$ and corresponds to the strike of the cleavage and shear planes enriched in phyllosilicates and developed during normal motion of the fault.

The Fig. 7 displays the correlation between porosity and permeability of samples located in the core zone and host sandstone. The samples located in the host sandstone show a constant value of permeability comprised between 0.05 and $0.1 \mathrm{mD}$ when the porosity increases between 1 to $2.5 \%$. This highlights that the low increase of porosity has no effect on the permeability because the pores are not well-connected.

The highly deformed samples present the highest permeability values. The strong increase of permeability (up to $1 \mathrm{mD}$ ) in the samples having the highest porosity values (4\%) suggests the presence of well-connected micropores in the horizontal and parallel direction of the fault azimuth. Moreover, we can observe a point out of the cluster of the highly deformed samples, with the highest permeability value $(1.2 \mathrm{mD})$ but an intermediate porosity value $(2.4 \%)$. It corresponds to the porosity and permeability measurements obtained on the core presented on Fig. 7. This core shows a well developed cleavage plane. This single cleavage plane was not sufficient to generate an important increase of porosity but it allowed an important increase of permeability. 


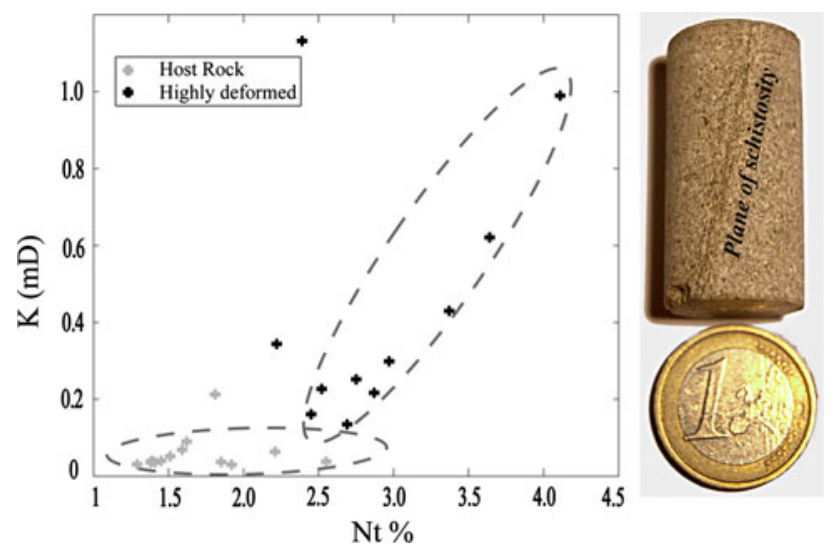

Fig. 7 Plot of permeability (K) versus total porosity (Nt). Permeability values are values from the three directions. Grey crosses nonaltered host sandstone values (samples showing present day meteoric alteration are excluded); black crosses deformed samples values. The number of crosses is superior to the number of samples because for each sample, several cores have been made (see Table 2)

\subsection{Phyllosilicates}

\subsubsection{Phyllosilicates mineralogy}

According to optical microscope observations and point counting analyses, phyllosilicates (mica and chlorite) represent 9 to $15 \%$ of the undeformed sandstones but $25-32 \%$ of the deformed sandstones (Table 1; Figs. 4, 5a).

XRD analyses performed on the clay fraction $(<2 \mu \mathrm{m})$ and the $2-16 \mu \mathrm{m}$ fraction from the host sandstone as well as from the deformed and highly deformed zones of the fault core zone (Fig. 8) show that the clay $(<2 \mu \mathrm{m})$ and $2-16 \mu \mathrm{m}$ fractions present similar mineralogical assemblages. In the $2-16 \mu \mathrm{m}$ fraction XRD patterns, it can be seen that feldspar reflections are less intense in highly deformed samples relative to white mica and quartz reflections. This result confirms the point counting analyses which suggest that feldspar becomes less abundant with increasing rate of deformation (Table 1). Furthermore, scanning electron microscope images shows that the decrease of K-feldspar content in highly deformed sample can be related to the stronger alteration of K-feldspar into white mica along shear planes (Fig. 4e).

The absence of expandable clays (i.e. smectite) in the $<2 \mu \mathrm{m}$ fraction has been confirmed by XRD analyses of glycolated clay fractions. On the $<2 \mu \mathrm{m}$ fraction XRD patterns, the chlorite $(001)$ reflections are particularly intense in the highly deformed samples.

High magnification optical microscope images and scanning electron microscope observations show that white mica and chlorite are preferentially concentrated along the cleavage and shear planes (Fig. 4d, f). Chlorite is often
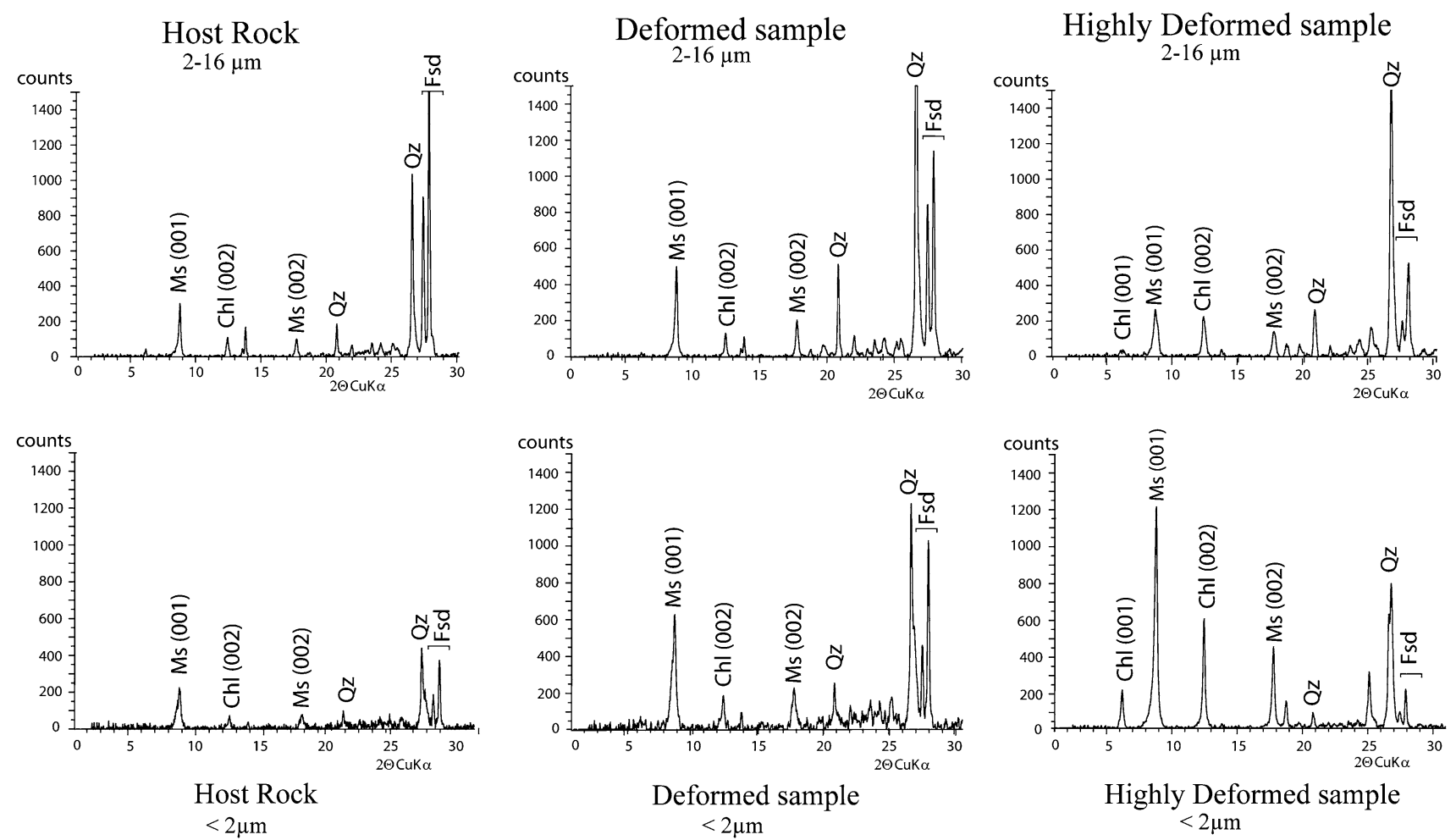

Fig. 8 Typical XRD diffractometers patterns obtained on the $<2 \mu \mathrm{m}$ fraction and the $2-16 \mu \mathrm{m}$ fraction of host sandstone, deformed and highly deformed samples after air dried treatment. $M s$ white mica, $C h l$ chlorite, $Q z$ quartz, $F s d$ feldspars 

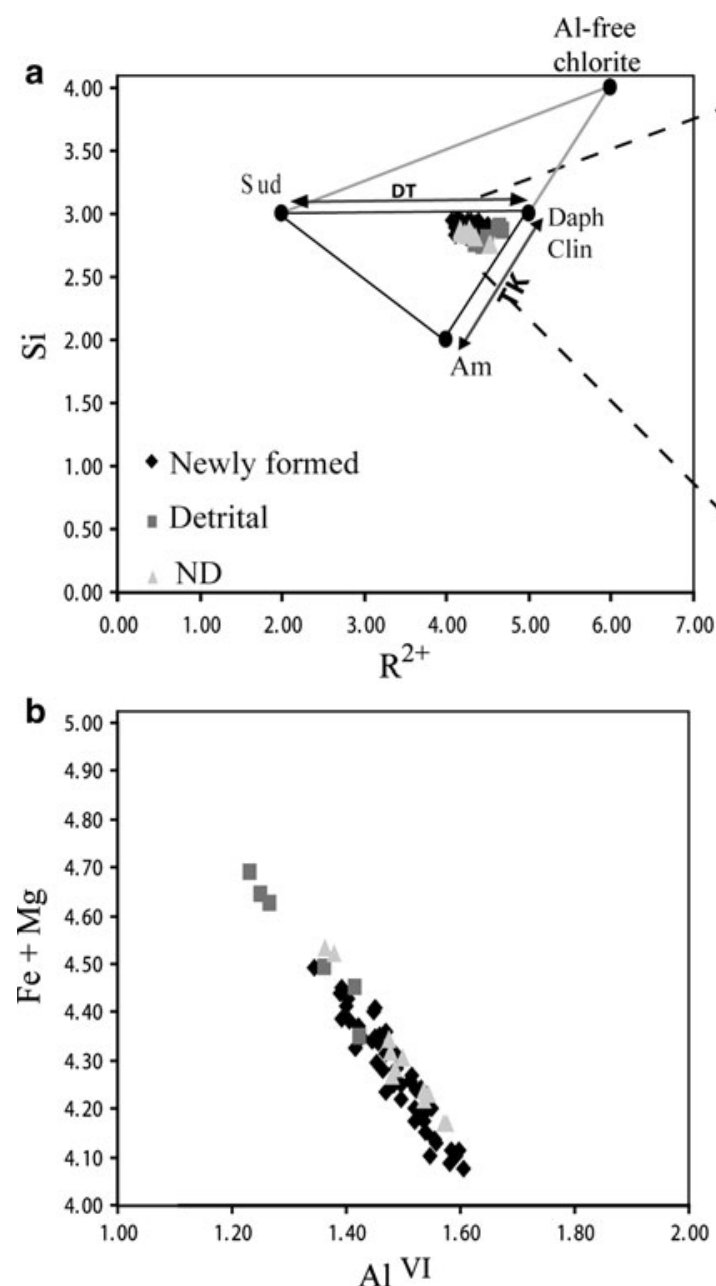

Fig. 9 a Si-R2+ graphic of detrital, newly formed and non determined (ND) chlorite compositions. End-members compositions of Vidal et al. (2001) and Inoue et al. (2009) have also been reported. Sud sudoïte, Am amesite, Daph daphnite, Clin clinochlore, TK Tschermak substitution, $D T$ di/trioctahedral substitution. b Fe $+\mathrm{Mg}$ -

located in the middle of the shear veins and white mica occurs at the borders (Fig. 4f). The size of the newlyformed phyllosilicate particles located in shear veins of highly deformed samples ranges from $<2$ to about $10 \mu \mathrm{m}$.

\subsubsection{Chemical composition of phyllosilicates}

The chemical composition of newly-formed chlorite (Fig. 4) located along shear planes and large detrital chlorite was determined by microprobe analyses (Online Resource 1; Fig. 9). The results show that newly formed chlorite as well as detrital chlorite have a chemical composition close to the clinochlore/daphnite pole (Fig. 9a). They are iron-rich chlorite (between 2.14 and 2.94 a.p.f.u for $\mathrm{Fe}$ ). Figure 9 shows chemical variations between detrital and newly-formed chlorite particles. A higher Si content associated with a lower $\mathrm{Fe}+\mathrm{Mg}$ content in newly-

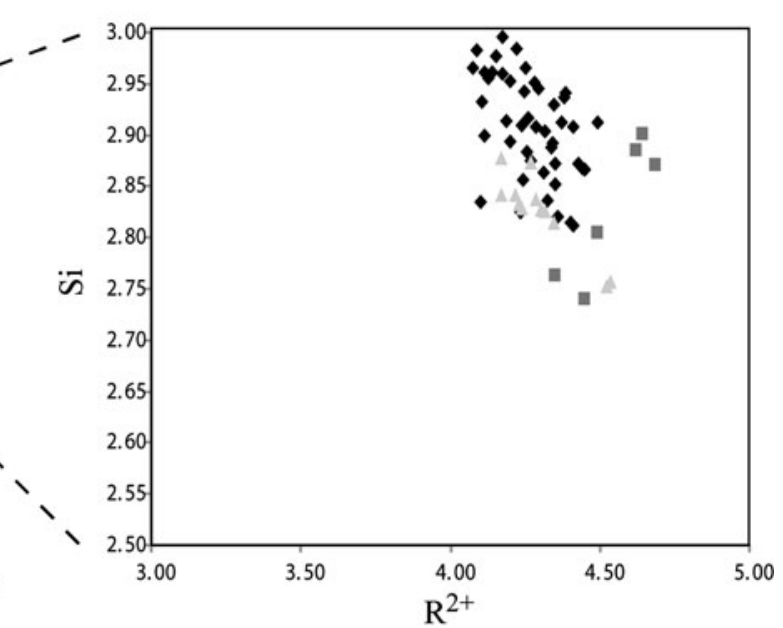

AlVI graphic of detrital, newly formed and non-determined (ND) chlorite compositions. This graphic shows the chemical variations of chlorite due to the DT di/trioctahedral substitution and Tschermak substitution

formed chlorite can be observed, the total alumina content remaining constant. These chemical variations between detrital and newly-formed chlorite are in agreement with Hillier and Velde (1991) who observed that diagenetic chlorite particles contain higher $\mathrm{Si}$ content, lower total $(\mathrm{Fe}+\mathrm{Mg})$ contents and lower octahedral occupancy than metamorphic chlorite particles with similar alumina contents.

Moreover, chlorite compositions can be expressed as the activities of the end-members determined by Vidal et al. (2001), as well as those defined by Inoue et al. (2009) (Fig. 9a). Therefore, the temperatures of chlorite formation can be determined using the thermodynamic thermometers from Vidal et al. $(2005,2006)$ and Inoue et al. (2009) (Fig. 10; Online Resource 1). Temperatures calculated by the model developed by Vidal et al. $(2005,2006)$ range from 143 to $232{ }^{\circ} \mathrm{C}$ for the newly formed chlorite 
Fig. 10 Temperatures of chlorite formation determined using the thermodynamic thermometers from Vidal et al. $(2005,2006)$ and Inoue et al. (2009). a Temperaturefrequency of newly-formed, detrital and non-determined chlorite (ND). b Correlation between temperatures determined by the thermodynamic thermometers from Vidal et al. (2005, 2006) and Inoue et al. (2009)
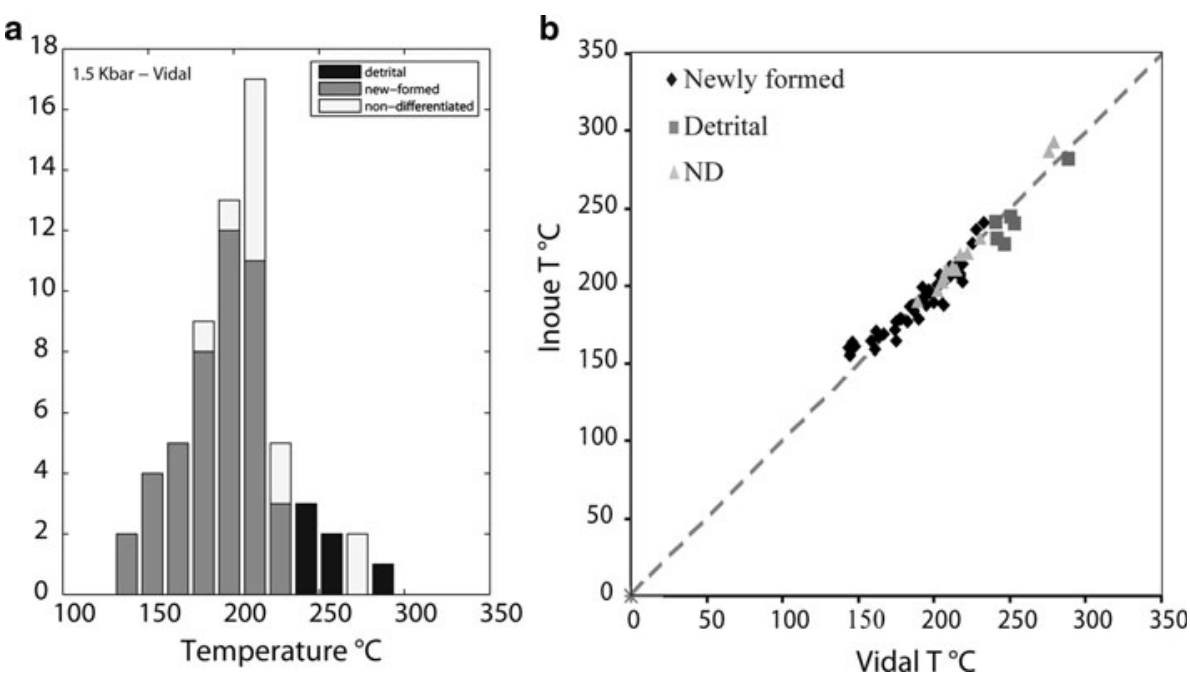

(Fig. 10a), with a maximum values between 170 and $210{ }^{\circ} \mathrm{C}$ and a mean value at $200 \pm 20{ }^{\circ} \mathrm{C}$. A simultaneous estimation of $\mathrm{Fe}^{3+}$ in chlorite has been done. Values obtained are specified in Online Resource 1 and are between 0.2 and 0.45 . Temperatures calculated by the model developed by Inoue et al. (2009) are very similar, ranging from 148 to $241{ }^{\circ} \mathrm{C}$ (Fig. 10b). Detrital chlorite is characterized by higher temperature of formation, from 250 to $290{ }^{\circ} \mathrm{C}$. The large range of temperature obtained for newly formed chlorite can be partly related to contamination effect. Indeed some chlorite analyses display a total $\mathrm{CaO}+\mathrm{Na}_{2} \mathrm{O}+\mathrm{K}_{2} \mathrm{O}$ between 0.3 and $0.5 \%$ (Online Resource 1). These analyses correspond to the lowest temperature measurements. The presence of such interlayer cations in the chlorite compositions can be related to the presence of chlorite-smectite mixed layers or to contamination of the chlorite analyses by the micas, which are generally closely associated to chlorite in the shear veins (see SEM images, this study). The occurrence of mixed layer would have an effect on the chlorite structural formulae (Lopez-Munguira et al. 2002). Moreover, interlayer cation content in mixed layers also affects to octahedral and tetrahedral substitutions. For this reason, the chlorite geothermometer cannot be used in the presence of mixed layer. In the studied samples, the absence of mixed layer is attested by the lack of difference between air dried and EGC-treated XRD diagrams. This indicates that chlorites are free of any interstratification. The alkali content measured on few chlorite analyses can be then related to mica contamination due to the large size of the electron beam during the microprobe analyses. If we consider this contamination effect, the significant temperature range of newly formed chlorite (free of any contamination) is between 180 and $220{ }^{\circ} \mathrm{C}$.

Figure 11 shows that composition of white mica can be divided in two categories: detrital white mica with low $\mathrm{FeO}$ and $\mathrm{MgO}$ content (close to $10 \%$ ) and newly formed white

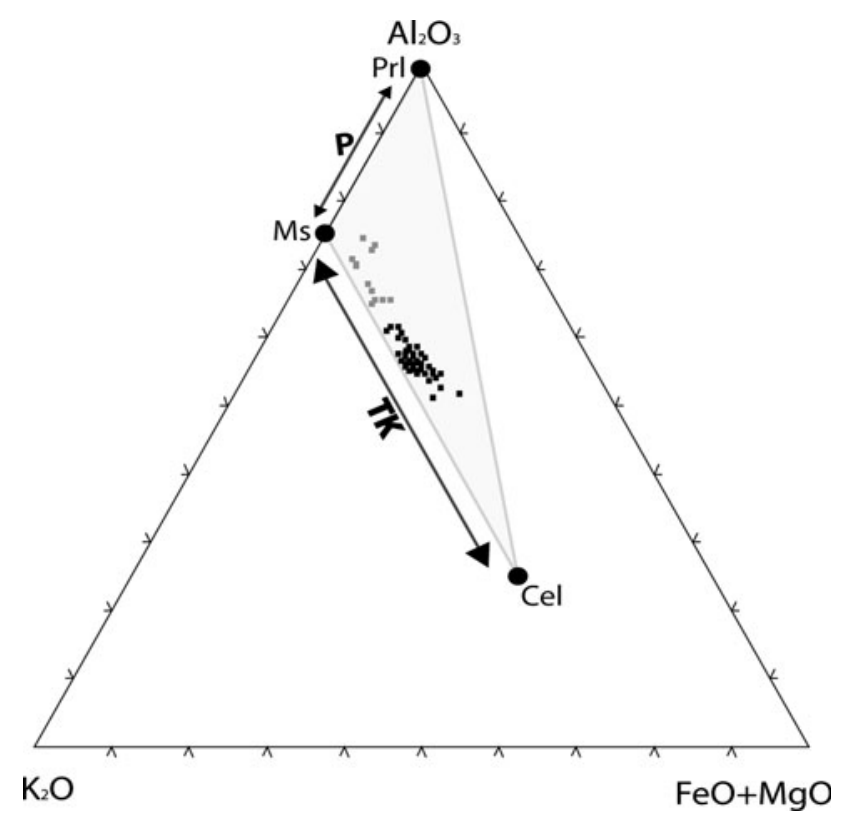

Fig. $11 \mathrm{Al}_{2} \mathrm{O}_{3}-\mathrm{K}_{2} \mathrm{O}-\mathrm{FeO}+\mathrm{MgO}$ ternary plot of white mica compositions. End-members compositions have also been reported. $\mathrm{Prl}$ pyrophyllite, Ms muscovite, Cel celadonite. Grey points detrital white mica; dark points newly-formed white mica, TK Tschermak substitution, $P$ pyrophyllitic substitution

mica with the highest $\mathrm{FeO}$ and $\mathrm{MgO}$ content (close to $25 \%$ ) (Online Resource 2). This variation in composition corresponds to the Tschermak substitution (TK) with IVAlVIAl substituted by IVSiVI(Mg,Fe) in newly-formed mica, leading to a redistribution of charges between the tetrahedral and octahedral layers but maintaining overall charge balance. The dispersion of the analyses of the newly formed and detrital micas can be partly explained by the analyses of mixed particles with microprobe. Indeed, in the shear plane both types of micas can be intimately associated. 


\section{Discussion}

\subsection{Origin and conditions of phyllosilicates formation}

The detrital and newly formed origin of white mica and chlorite is attested by a difference in shape and in chemical composition.

The lower $\mathrm{FeO}$ and $\mathrm{MgO}$ content of the detrital white mica than newly-formed white mica traduces a difference of fluid compositions and environment of formation. Detrital phyllosilicates are probably derived from the granites and low-grade metamorphic basement rocks (Hercynian basement) outcropping in the MauresEstérel and Corsica-Sardinia massifs (Apps et al. 2004, Garcia et al. 2004) while newly formed phyllosilicates are related to the Restefond fault activity. The increase in newly formed white mica is clearly related to the increase of the strain intensity (Fig. 8; Table 1) and to the alteration of K-feldspars (Fig. 4f). The illitization of feldspar occurs in the presence of fluids following the equation

$$
\begin{aligned}
2 \mathrm{H}^{+}+3 \mathrm{KAlSi}_{3} \mathrm{O}_{8}+12 \mathrm{H}_{2} \mathrm{O} \Rightarrow & 2 \mathrm{~K}^{+}+\mathrm{KAl}_{3} \mathrm{Si}_{3} \mathrm{O}_{10}(\mathrm{OH})_{2} \\
& +6 \mathrm{H}_{4} \mathrm{SiO}_{4}
\end{aligned}
$$

According to this equation, illitization of feldspar necessitates the presence of water. This reaction is more efficient in the fault core zone where water-rock interactions during deformation are stronger than in the host sandstone.

The newly-formed chlorite is associated with newlyformed white mica along the shear planes. The mean $200 \pm 20{ }^{\circ} \mathrm{C}$ temperature of formation estimated with the Vidal et al. (2005, 2006) and Inoue et al. (2009) geothermometers is in agreement with the temperature estimation (around $200{ }^{\circ} \mathrm{C}$ ) by Labaume et al. (2008b) using a petrographic study in non-deformed Grès d'Annot samples from the same area. It is also consistent with the maximum temperatures of $220{ }^{\circ} \mathrm{C}$ reached by the same non-deformed Grès d'Annot as deduced from vitrinite reflectance (Labaume et al. 2008a).

The burial depth of faulting is estimated based on a mean geothermal gradient comprised between 25 to $30{ }^{\circ} \mathrm{Ckm}^{-1}$ in the foreland basin and its crystalline substratum (Bigot-Cormier et al., 2006; Sanchez et al., 2011). The precipitation of newly formed chlorite and illitization of K-feldspars might occur at depths comprised between 6.5 to $8 \mathrm{~km}$. These depths indicate that faulting occurred in relatively deep burial conditions. The burial condition of faulting in a well-lithified sandstone contrasts with those of Bouroullec et al. (2004), Lansigu and Bouroullec (2004) and Pochat and Driessche (2007) who described syn-sedimentary normal faults affecting the Grès d'Annot a few kilometers from the Restefond fault, characterized by local sedimentary disturbances close the faults. This shows that the faulting of the study area occurred during at least two stages: early syn-sedimentary faulting and later deep-burial faulting.

\subsection{Role of the phyllosilicates on fault zone petrophysic properties}

The petrophysical investigations on the Restefond fault demonstrate that sandstones in the fault core zone are more porous and permeable than the host sandstones. This slight increase of porosity and the increase of permeability in the highly deformed sandstones compared to the host sandstone can be related to the presence of micropores located between the syn-kinematic newly-formed phyllosilicate particles that characterize the highly deformed sandstones. Indeed, the fact that the newly formed phyllosilicates are concentrated along the $\mathrm{S}-\mathrm{C}$ surfaces yields a good connection between the micropores, making the $\mathrm{S}-\mathrm{C}$ structures preferential channels for fluid-flows and consequently playing an essential role in the petrophysical properties of the fault-zone. The preferential fluid-flow channels along S-C structures have been previously shown by Faulkner and Rutter (1998) for clay-bearing fault gouge in the Carboneras strike-slip fault where preferential fluid-flows occurred vertically. It appears that the preferential fluidflow along S-C structures is controlled by the kinematic of the fault with vertical preferential fluid-flows for strike-slip fault (Faulkner and Rutter 1998) and horizontal parallel to the fault azimuth fluid-flows for normal fault (this study).

Previous studies focused on the hydraulic behavior of faults affecting different types of sandstones (i.e. low or high porosity and poorly or well lithified sandstones) in shallow burial contexts highlight the key role played by mechanical processes (i.e. grain size reduction) on the petrophysical properties (Antonellini and Aydin 1994; Rawling and Goodwin 2003; Balsamo et al. 2010). By contrast, the present study shows the key role played by the mineralogical transformations (i.e. phyllosilicates crystallisation) on the petrographical properties of a fault zone affecting low-porosity, well-lithified sandstones under deep burial conditions. This study thus highlights that the fault zone hydraulic behavior results from the temperaturedependent water-rock interactions which induce the mineralogical transformations.

\section{Conclusion}

The results of the structural, mineralogical and petrophysical study of the Restefond fault which affects low 
porosity and well lithified arkosic sandstones can be summarized as follows:

1. Within the fault core zone, the deformation is represented by intragranular to transgranular fractures filled with quartz, calcite or newly formed phyllosilicates, intense pressure-solution of quartz and feldspar at grain contacts and development of $\mathrm{S}-\mathrm{C}$ structures enriched with newly formed phyllosilicates. The newly-formed platy phyllosilicate minerals are white mica and chlorite aligned along the shearing direction. Their crystallization is favored by the burial conditions allowing fluid-rock interaction, represented notably by K-feldspars illitization. The burial depth during faulting is estimated at $6.5-8 \mathrm{~km}$ based on the temperature of formation of the newly-formed chlorite at $200 \pm 20{ }^{\circ} \mathrm{C}$.

2. Petrophysical measurements show an increase of permeability of one order of magnitude parallel to the fault azimuth in the sandstones lenses forming the fault core zone compared to the host sandstone. This increase of permeability is due to the increase of newly-formed phyllosilicates content in the $\mathrm{S}-\mathrm{C}$ structures and in which micropores form connected fluid conducts between clay minerals.

This study thus points out that preferential fluid-flow in a fault zone formed in deep burial condition is controlled by the mineralogical transformations related to temperature-dependent fluid-rock interactions and more precisely by the phyllosilicate crystallization. Hence, this study provides a new approach for considering fluid-flow in lowporosity and well-lithified sandstones affected by faults in deep burial conditions.

Acknowledgments We thank P. Lanari and O. Vidal for their guidances regarding the thermodynamic thermometers. We thank D. Convert-Gaubier from the University of Franche-Comté (Besançon) for his technical support. Reviews by J. Jimenez-Millan, an anonymous reviewer and guest editor F. Nietto-Garcia were very helpful.

\section{References}

Adatte, T., Stinnesbeck, W., \& Keller, G. (1996). Lithologic and mineralogic correlations of near $\mathrm{K} / \mathrm{T}$ boundary clastic sediments in NE Mexico: Implication for origin and nature of deposition. Sp. publications. Geological Society of America, 307, 211-226.

Antonellini, M., \& Aydin, A. (1994). Effect of faulting on fluid flow in porous sandstones; petrophysical properties. AAPG Bulletin, 78, 355-377.

Antonellini, M., Aydin, A., \& Orr, L. (1999). Outcrop aided characterization of a faulted hydrocarbon reservoir: Arroyo Grande oil field, California, USA. In W. C. Haneberg, P. S. Mozley, J. C. Moore, \& L. B. Goodwin (Eds.), Faults and Subsurface Fluid Flow in the Shallow Crust (pp. 7-26). Washington, DC: American Geophysical Union, Monograph.
Apps, G., Peel, F., \& Elliott, T. (2004). The structural setting and palaeogeographical evolution of the gres d'annot basin. Geological Society, London, Special Publications, 221, 65-96.

Aydin, A. (1978). Small faults formed as deformation bands in sandstone. Pure and Applied Geophysics, 116, 913-930.

Aydin, A. (2000). Fractures, faults, and hydrocarbon entrapment, migration and flow. Marine and Petroleum Geology, 17, $797-814$.

Balsamo, F., Storti, F., Salvini, F., Silva, A., \& Lima, C. (2010). Structural and petrophysical evolution of extensional fault zones in low-porosity, poorly lithified sandstones of the Barreiras formation, NE Brazil. Journal of Structural Geology, 32, $1806-1826$.

Bigot-Cormier, F., Sosson, M., Poupeau, G., Stephan, J., \& Labrin, E. (2006). The denudation history of the Argentera Alpine external crystalline massif (western Alps, France-Italy) an overview from the analysis of fission tracks in apatites and zircons. Geodinamica Acta, 16(6), 455-473.

Bouroullec, R., Cartwright, J. A., Johnson, D. J., Lansigu, C., Quémener, J.-M., \& Savanier, D. (2004). Syndepositional faulting in the Grés d'Annot Formation, SE France: Highresolution kinematic analysis and stratigraphic response to growth faulting. In P. Joseph \& S. Lomas (Eds.), Deep-water sedimentation in the Alpine Basin of SE France: New perspectives on the Grès d'Annot and related systems (pp. 241-265). London: Geological Society, London, Special Publications.

Caine, J. S., Evans, J. P., \& Forster, C. B. (1996). Fault zone architecture and permeability structure. Geology, 24, 1025-1028.

Corsini, M., Ruffet, G., \& Caby, R. (2004). Alpine and late-hercynian geochronological constraints in the Argentera massif (western Alps). Eclogae Geologicae Helvetiae, 97, 3-15.

Du Bernard, X. (2002). Les modes de localisation et de propagation de la rupture dans les zones de failles affectant les grès, et les facteurs qui les contrôlent. Ph.D. Dissertation, Université Joseph Fourier, Grenoble 1, France.

Du Fornel, E. D., Joseph, P., Desaubliaux, G., Eschard, R., Guillocheau, F., Lerat, O., Ravanne, C., \& Sztràkos, K. (2004). The southern grès d'Annot outcrops (French Alps): An attempt at regional correlation. In P. Joseph \& S. Lomas (Eds.), Deepwater sedimentation in the Alpine Basin of SE France: New perspectives on the Grès d'Annot and related systems (pp. 137-160). London: Geological Society London, Special Publication.

Elliott, T., Apps, G., Davies, H., Evans, M., Ghibaudo, G., Graham, R.H. (1985). A structural and sedimentological traverse through the tertiary foreland basin of the external Alps of south-east France. In P. A. Homewood, P. William \& G. Allen (Eds.), International Symposium on foreland Basins (pp. 39-73). Excursion Guidebook Fribourg International Association of Sedimentologists.

Faulkner, D. R., \& Rutter, E. H. 1998. The gas permeability of claybearing fault gouge at $20{ }^{\circ} \mathrm{C}$. In G. Jones, Q. J. Fisher, \& R. J. Knipe (Eds.) Faulting, Fault Sealing and Fluid Flow in Hydrocarbon Reservoirs (pp. 147-156). Geological Society, London, Special Publications (Vol. 147).

Fisher, Q. J., \& Knipe, R. J. (2001). The permeability of faults within siliciclastic petroleum reservoirs of the north sea and norwegian continental shelf. Marine and Petroleum Geology, 18, $1063-1081$.

Fossen, H., Schultz, R. A., Shipton, Z. K., \& Mair, K. (2007). Deformation bands in sandstone: A review. Journal of the Geological Society, London, 164, 755-769.

Garcia, D., Joseph, P., Marechal, B., \& Moutte, J. (2004). Patterns of geochemical variability in relation to turbidite facies in the gres d'Annot formation. In P. Joseph \& S. Lomas (Eds.), Deep-water sedimentation in the Alpine Basin of SE France: New perspectives 
on the Grès d'Annot and related systems (pp. 349-365). London: Geological Society London, Special Publications.

Haines, S. H., \& Van der Pluijm, B. A. (2008). Clay quantification and $\mathrm{Ar} / \mathrm{Ar}$ dating of synthetic and natural gouge: Application to the Miocene Sierra Mazatan detachment fault, Sonora, Mexico. Journal of Structural Geology, 30, 525-538.

Hillier, S., \& Velde, B. (1991). Octahedral occupancy and the chemical composition of diagenetic (low temperature) chlorites. Clay Minerals, 26, 149-168.

Inoue, A., Meunier, A., Patrier-Mas, P., Rigault, C., Beaufort, D., \& Vieillard, P. (2009). Application of chemical geothermometry to low-temperature trioctahedral chlorite. Clays and Clay Minerals, 57, 371-382.

Joseph, P., \& Lomas, S. A. (2004). Deep-water sedimentation in the alpine foreland basin of SE France: New perspectives on the gres d'Annot and related systems: An introduction. In P. Joseph \& S. Lomas (Eds.), Deep-water sedimentation in the Alpine Basin of SE France: New perspectives on the Grès d'Annot and related systems (pp. 1-16). London: Geological Society London, Special Publications.

Kerckhove, C. (1969). La zone du flysch dans les nappes de l'embrunaisubaye (Alpes occidentales). Géologie Alpine, 45, 1-202.

Kübler, B. (1964). Les argiles, indicateurs de métamorphisme. Revue de 1'Institut Francais du Petrole et Annales des Combustible Liquides, 19, 1093-1112.

Labaume, P., Arnaud, N., Buatier, M., Charpentier, D., Chauvet, A., Chirouze, F., et al. (2008a). Contrôle tectonique de la diagenèse d'une formation turbiditique d'avant-chaîne, exemple des grès d'Annot. Rapport Total: Alpes externes Franco-Italiennes.

Labaume, P., Jolivet, M., Souquière, F., \& Chauvet, A. (2008b). Tectonic control on diagenesis in a foreland basin: Combined petrologic and thermochronologic approaches in the grès d'Annot basin (Late Eocene-EarlyOligocene, French, Italian external Alps). Terra Nova, 20, 95-101.

Labaume, P., Ritz, J. F., \& Philip, H. (1989). Failles normales récentes dans les alpes sud-occidentales: Leurs relations avec la tectonique compressive. Comptes Rendus de l'Académie des Sciences, 308, 1553-1560.

Lansigu, C., \& Bouroullec, R. (2004). Staircase normal fault geometry in the Grès d'Annot (SE France). In P. Joseph \& S. Lomas (Eds.), Deep-water sedimentation in the Alpine Basin of SE France: New perspectives on the Grès d'Annot and related systems (pp. 223-240). London: Geological Society Special Publication.

Lopez-Munguira, A., Nietto, F., \& Morata, D. (2002). Chlorite composition and geothermometry: A comparative HRTEM/ AEM-EMPA-XRD study of Cambrian basic lavas from the Ossa Morena Zone, SW Spain. Clay Minerals, 37, 267-281.
McBride, E. F. (1963). A classification of common sandstones. Journal of Sedimentary Petrology, 33, 664-669.

Pochat, S., \& Driessche, J. V. D. (2007). Impact of synsedimentary metre-scale normal fault scarps on sediment gravity flow dynamics: An example from the grès d'Annot formation, SE France. Sedimentary Geology, 202, 796-820.

Rawling, G. C., \& Goodwin, L. B. (2003). Cataclasis and particulate flow in faulted, poorly lithified sediments. Journal of Structural Geology, 25, 317-331.

Rice, J. (1992). Chapter 20 fault stress states, pore pressure distributions, and the weakness of the San Andreas fault. In B. Evans \& T. F. Wong (Eds.), Fault Mechanics and Transport Properties of Rocks A Festschrift in Honor of W. F. Brace (pp. 529-553). International Geophysics.

Riche, P., Trémolières, P., Ravenne, C., \& Vially, R. (1987). Sédimentation et tectonique dans le bassin marin éocène supérieur-oligocène des Alpes du sud. Oil and Gas Science and Technology Revue d'IFP, 42, 529-553.

Sanchez, G., Rolland, Y., Schneider, J., Corsini, M., Oliot, E., Goncalves, P., et al. (2011). Dating low-temperature deformation by ${ }^{40} \mathrm{Ar} /{ }^{39} \mathrm{Ar}$ on white mica, insights from the argenteramercantour massif (SW Alps). Lithos, 125, 521-536.

Seranne, M. (1999). The Gulf of Lion continental margin (NW Mediterranean) revisited by IBS: An overview. Geological Society, London, Special Publications, 156, 15-36.

Seward, D., Ford, M., Bürgisser, J., Lickorish, H., Williams, E.A., Meckellii, L.D. (1999). Preliminary results of fission-track analyses in the Southern Pelvoux area, SE France. In G. Gosso, F. Jadoul, M. Sella, M. I. Spalla (Eds.), 3rd Workshop on Alpine Geological Studies, Biella-Oropa Italie), September 29thOctober 1st 1999 (pp. 25-31). Memorie di Scienze Geologische.

Vidal, O., De Andrade, V., Lewin, E., Munoz, M., Parra, T., \& Pascarelli, S. (2006). P-T-Deformation- $\mathrm{Fe}^{3+} / \mathrm{Fe}^{2+}$ mapping at the thin section scale and comparison with XANES mapping: Application to a garnet-bearing metapelite from the Sambagawa metamorphic belt (Japan). Journal of Metamorphic Geology, 24, 669-683.

Vidal, O., Parra, T., \& Trotet, F. (2001). A thermodynamic model for $\mathrm{Fe}-\mathrm{Mg}$ aluminous chlorite using data from phase equilibrium experiments and natural pelitic assemblages in the $100.600{ }^{\circ} \mathrm{C}$, $1.25 \mathrm{kbar}$ range. American Journal of Science, 6(557), 592.

Vidal, O., Parra, T., \& Vieillard, P. (2005). Thermodynamic properties of the Tschermak solid solution in Fe-chlorite: Application to natural examples and possible role of oxidation. American Mineralogist, 90, 347-358.

Vrolijk, P., \& Van der Pluijm, B. A. (1999). Clay gouge. Journal of Structural Geology, 21, 1039-1048. 